\title{
Classification of Micrococci on the Basis of Deoxyribonucleic Acid Homology
}

\author{
By NORIKO OGASAWARA-FUJITA AND K. SAKAGUCHI \\ Laboratory of Microbial Biochemistry, Mitsubishi-Kasei Institute of Life Sciences, \\ I I Minomiooya, Machida, Tokyo, Japan
}

(Received I September 1975)

\begin{abstract}
SUMMARY
The DNA homology relationships of 25 micrococci ( 15 strains of Micrococcus, eight strains of Sarcina and two strains of Staphylococcus) were studied by the deoxyribonucleic acid hybridization method using nuclease $S_{1}$, an endonuclease specific for single-stranded DNA molecules. Nineteen of the strains were classified into three groups. Group I contained Micrococcus lysodeikticus IAMI056, M. luteus IAMI IOIO, M. flavus IAMI 2005 and IAMI 2006, Sarcina flava IAMI 2007 and IAMI 2008, $S$. subflava IAMI2009, $S$. lutea ATCC38I and ATCC382, and $M$. luteus IAMII006. Group II contained $M$. roseus IAMI3I5, ATCC4I2, ATCCI85 and IAMI 295. Group III contained $S$. lutea IAMI099, IFO3232 and ATCC383, $M$. varians ATCC399 and Staphylococcus lactis ATCCI5306. Micrococcus luteus IAMI097, M. varians ATCCI9099 and ATCCI 9IOO, M. conglomeratus IAMI 459 and IAMI 470, and St. aureus IAMIOI I could not be assigned to any of the three groups.

The grouping corresponds to that derived from the results of differential lysis by lysozyme, 'lytic enzyme 2' from Cytophaga sp., or Streptomyces albus G enzyme; and to types of peptidoglycan in the cell walls and genetic transformation. The usefulness of classification based on sensitivity to various lytic enzymes was demonstrated. Group I probably coincides with $M$. luteus of Bergey's Manual of Determinative Bacteriology (1974), and groups II and III with $M$. roseus and $M$. varians respectively.
\end{abstract}

\section{INTRODUCTION}

Since I96I, many investigators have applied various DNA hybridization methods to the elucidation of the genetic relationships between a variety of bacteria (Schildkraut, Marmur \& Doty, 196I; McCarthy \& Bolton, I963; Brenner et al., I969, 1972; Okanishi, Akazawa \& Umezawa, 1972; Boling, 1972; De Ley et al., 1973). The DNA hybridization method using nitrocellulose membranes is common today, but this method has the disadvantage that DNA fixed on nitrocellulose membranes is released during incubation at high temperatures (Okanishi \& Gregory, 1970). Recently, nuclease $\mathrm{S}_{1}$ isolated from Aspergillus oryzae, which is specific for single-stranded nucleic acid (Ando, I966), was successfully used in improving the nitrocellulose-membrane DNA hybridization method. This endonuclease digests only the single-stranded DNA portion that has not hybridized. Crosa, Brenner \& Falkow (1973) studied the nucleotide sequence relatedness between homologous and heterologous chromosomal and plasmid DNA by the DNA hybridization method with nuclease $S_{1}$ and showed that this method permitted an accurate, reproducible and rapid determination of the extent of polynucleotide sequence homology. In this study, we examined the DNA homology relationships, by DNA hybridization followed by nuclease $S_{1}$ digestion, among species of the genus Micrococcus, including aerobic Sarcina strains which had been proved to belong to the genus Micrococcus by Kocur \& Martinec (I965) and Hubalek (I969). 
Table I. Strains used, and their lytic enzymes

\begin{tabular}{|c|c|c|c|}
\hline Species & Source* & Other names or numbers* & $\begin{array}{c}\text { Lytic } \\
\text { enzyme }\end{array}$ \\
\hline Micrococcus lysodeikticus & IAMIO56 & АТСC4698, M. luteus ССмі 69 & I \\
\hline M. luteus & IAMI 1006 & Ссм840, $M$. ureae АТсC408 & I \\
\hline M. luteus & IAMI IOIO & CCM410, S. lutea АТсC272 & I \\
\hline M. luteus & IAMI097 & АТсC398, ССм810 & I \\
\hline M. flavus & IAMI 2005 & ATCC400, CCM210 & I \\
\hline M. flavus & IAMI 2006 & ATCCI 4452 & I \\
\hline M. varians & ATCC 399 & & 3 \\
\hline M. varians & ATCCI 9099 & & I \\
\hline M. varians & ATCCI9I00 & & $\mathbf{I}$ \\
\hline M. conglomeratus & IAM I 459 & ATCCI9IOI, CCM2I 34 & $\mathbf{I}$ \\
\hline M. conglomeratus & IAM 1470 & ATCC19102, CCM2I 35 & I \\
\hline M. roseus & ATCCI 85 & & 2 \\
\hline M. roseus & ATCC4I 2 & & 2 \\
\hline M. roseus & IAMI 3 I 5 & ССм679, $M$. rubens АТСС 86 & 2 \\
\hline$M$. roseus & IAMI 295 & $\operatorname{ATCC} 9815$ & 2 \\
\hline Sarcina flava & IAM 12007 & $\operatorname{ATCC} 147$ & I \\
\hline S. flava & IAMI 2008 & ATCC 540 & I \\
\hline S. subflava & IAMI 2009 & АТСC $7468, M$. luteus CCMIO 48 & $\mathbf{I}$ \\
\hline S. lutea & IAMIO99 & AтCC934I & 3 \\
\hline S. lutea & IFO3232 & & 3 \\
\hline S. lutea & $\operatorname{ATcc} 38 \mathrm{I}$ & & I \\
\hline S. lutea & ATCC 382 & & I \\
\hline S. lutea & ATCC 383 & & 3 \\
\hline Staphylococcus aureus & IAMIOII & ATCC $6538 p$ & 2 \\
\hline St. lactis & ATCCI 5306 & NCTC 7564 & 3 \\
\hline
\end{tabular}

* IAM, Institute of Applied Microbiology, Tokyo, Japan. ATcC, American Type Culture Collection, Maryland, U.S.A. CCM, Czechoslovak Collection of Micro-organisms, Brno, Czechoslovakia. NCTC, National Collection of Type Cultures, London, England. IFo, Institute for Fermentation, Osaka, Japan. $\dagger$ 1, Lysozyme; 2, 'lytic enzyme 2'; 3, Streptomyces albus G lytic enzyme.

\section{METHODS}

Bacteria. The strains employed, together with the lytic enzymes used to prepare their DNA, are listed in Table $\mathrm{r}$.

DNA preparation. Bacteria were collected by centrifuging at the beginning of the stationary phase. DNA was isolated by a modified version of the method of Saito \& Miura (1963). Bacteria were incubated at $37^{\circ} \mathrm{C}$ in one of three ways: I, with lysozyme (Sankyo, Tokyo, Japan) in SSC buffer (0. I 5 M-sodium chloride-0.0 I 5 M-sodium citrate); 2, with 'lytic enzyme 2' (Kyowa Hakko Kogyo, Tokyo, Japan; a product from Cytophaga sp. including $N$ acetylmuramyl-L-alanine amidase and peptidases) in $50 \mathrm{~mm}$-Tris- $\mathrm{HCl}, \mathrm{pH} 8.5$; or 3 , with Streptomyces albus G lytic enzyme (Petit, Munoz \& Ghuysen, 1966; kindly provided by Professor S. Kotani, Department of Dentistry, University of Osaka, Japan) in 5 mM-citrate buffer $\mathrm{pH}_{4} \cdot \mathrm{O}$, as indicated in Table I. Lysis was completed by addition of sodium lauryl sulphate (SLS) to give a final concentration of $0.4 \%(\mathrm{w} / \mathrm{v})$. The viscous suspension obtained was incubated with I $\mathrm{mg}$ of pronase E/ml (Kaken Kagaku, Tokyo, Japan) for $4 \mathrm{~h}$ at $37^{\circ} \mathrm{C}$. An equal amount of phenol saturated with $0 \cdot 1$ M-trizma base was added and mixed for $20 \mathrm{~min}$ at $4{ }^{\circ} \mathrm{C}$. The aqueous phase containing DNA was separated by centrifuging at $3000 \mathrm{rev} . / \mathrm{min}$ for $10 \mathrm{~min}$, and $6000 \mathrm{rev} . / \mathrm{min}$ for $15 \mathrm{~min}$. DNA was precipitated by adding twice the volume of cold ethanol and spooled on to a glass rod. The spooled DNA was dissolved in $0.1 \times$ SSC and the concentration of the solution was adjusted to SSC by adding Io $\times$ SSC. The DNA solution was incubated with $50 \mu \mathrm{g}$ pancreatic ribonuclease $/ \mathrm{ml}$ (Sigma) 
for $60 \mathrm{~min}$ at $37^{\circ} \mathrm{C}$, then $50 \mu \mathrm{g}$ of pronase $\mathrm{E} / \mathrm{ml}$ was added and the solution was incubated for a further $30 \mathrm{~min}$ at $37^{\circ} \mathrm{C}$. The phenol extraction and ethanol precipitation procedures were repeated. Ribonuclease and pronase $\mathrm{E}$ treatments were also repeated in most cases. DNA concentrations were estimated spectrophotometrically, assuming an extinction of $\mathrm{I} \cdot \mathrm{O}$ at $260 \mathrm{~nm}$ to be equal to $50 \mu \mathrm{g} \mathrm{ml}^{-1}$.

Labelled DNA was prepared by the same method from bacteria grown in the basal medium containing added $\mathrm{H}_{3}{ }^{33} \mathrm{PO}_{4}$ (carrier free, New England Nuclear, $0.8 \mathrm{mCi} / 50 \mathrm{ml}$ medium). Basal medium contained: I M-Tris- $\mathrm{HCl}$ buffer solution $\left(\mathrm{pH}_{7} \cdot 4\right)$, $10 \mathrm{ml}$; glucose, $0.4 \mathrm{~g}$; neopeptone (Difco), $0.5 \mathrm{~g} ; \mathrm{Na}_{2} \mathrm{SO}_{4}, 0.05 \mathrm{~g}$; salt solution, Io ml (stock composed of $5.4 \mathrm{~g}$ $\mathrm{NaCl}$, 3.0 $\mathrm{g} \mathrm{KCl}, \mathrm{I} \cdot \mathrm{I} \mathrm{g} \mathrm{NH}_{4} \mathrm{Cl}$, 0.I $\mathrm{g} \mathrm{MgCl}_{2}$, 0.0I $\mathrm{g} \mathrm{CaCl}_{2}, 0.2 \mathrm{mg} \mathrm{FeCl}$ and $100 \mathrm{ml}$ water) and distilled water to $100 \mathrm{ml}$. Over $90 \%$ of the isotope was incorporated into the bacteria and the radioactivity of prepared DNA was $\mathrm{I} \times 10^{5}$ to $4 \times 10^{5}$ c.p.m. $/ \mu \mathrm{g}$.

DNA was sheared to between $5 \times 10^{5}$ and $\mathrm{I} \times 10^{5}$ daltons by adding $\mathrm{NaOH}$ to $0.5 \mathrm{M}$ and incubating at $100^{\circ} \mathrm{C}$ for $7 \mathrm{~min}$. The molecular weight of the DNA was estimated by agarose gel electrophoresis with reference to $\lambda$-phage DNA treated with an endonuclease EcoRI (Aaij \& Borst, 1972; Allet et al., 1973). The DNA was then heated at $100{ }^{\circ} \mathrm{C}$ in $0.1 \times \mathrm{SSC}$ for $15 \mathrm{~min}$ and cooled rapidly in ice-water. The complete denaturation was checked by a nuclease $\mathrm{S}_{\mathbf{1}}$ digestion test.

DNA digestion by nuclease $S_{1}$. The reaction mixture $(7.5 \mathrm{ml})$ contained: 0.I M-sodium acetate $\left(\mathrm{pH}_{4} .5\right) ; 0.2 \mathrm{mM}^{-\mathrm{ZnSO}_{4}} ; 0.03 \mathrm{M}-\mathrm{NaCl} ; \mathrm{I} 600$ units of nuclease $\mathrm{S}_{1} / \mathrm{ml}$ (Seikagakukōgyō, Tokyo, Japan) and $20 \mu \mathrm{g}$ of DNA $/ \mathrm{ml}$. After incubation at $35^{\circ} \mathrm{C}$ for $40 \mathrm{~min}, 2.5 \mathrm{ml}$ of $20 \%(\mathrm{w} / \mathrm{v})$ trichloroacetic acid (TCA) was added. The TCA-insoluble DNA was collected on a nitrocellulose membrane filter (Sartorius, Göttingen, Germany; catalogue no. I I306, pore size $0.45 \mu \mathrm{m})$, washed with cold $5 \%(\mathrm{w} / \mathrm{v})$ TCA $(30 \mathrm{ml})$, and the radioactivity on the dried filter was determined with a toluene-based scintillator in a liquid scintillation spectrophotometer. One unit of nuclease $S_{1}$ is defined as the activity that produces $\mathrm{I} \mu \mathrm{g}$ acid-soluble deoxypentose-P in $30 \mathrm{~min}$, as determined by the diphenylamine method.

$D N A$ hybridization. Radioactive DNA ( $0.1 \mu \mathrm{g}, \mathrm{I} \times 10^{4}$ c.p.m.) from the reference strain, and unlabelled DNA ( $100 \mu \mathrm{g}$; denatured and sheared at $100{ }^{\circ} \mathrm{C}$ for $7 \mathrm{~min}$ in $0.5 \mathrm{M}-\mathrm{NaOH}$ ) from various strains, were neutralized and mixed in $0.1 \times \mathrm{SSC}(0.6 \mathrm{ml})$. Sodium chloride $(0.15 \mathrm{ml}$ of $2.0 \mathrm{M})$ was added to give a final concentration of $0.4 \mathrm{M}$ and the mixture was incubated with shaking at 75 or $85^{\circ} \mathrm{C}$ for $\mathrm{I} 2$ to $\mathrm{I} 8 \mathrm{~h}$. The mixture was then treated with nuclease $S_{1}$ and the radioactivity of the hybridized DNA was determined as described previously. The values were corrected for the radioactivity resistant to nuclease $S_{1}$ digestion which appeared by self-annealing of labelled DNA. The homology value is expressed as the percentage of radioactivity in heterologous hybridized DNA relative to that in homologous hybridized DNA.

Thermal stability of the hybridized DNA. The hybridized DNA solution was diluted with distilled water to four times its volume, heated at various temperatures for $15 \mathrm{~min}$, and cooled rapidly. Dissociated DNA was digested by nuclease $S_{1}$. The thermal stability of the hybridized DNA was expressed by plotting the percentage of DNA dissociated (DNA digested by nuclease $S_{1}$ ) against temperature. 


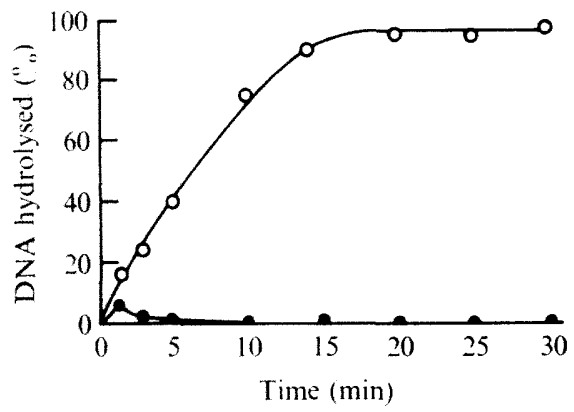

Fig. I

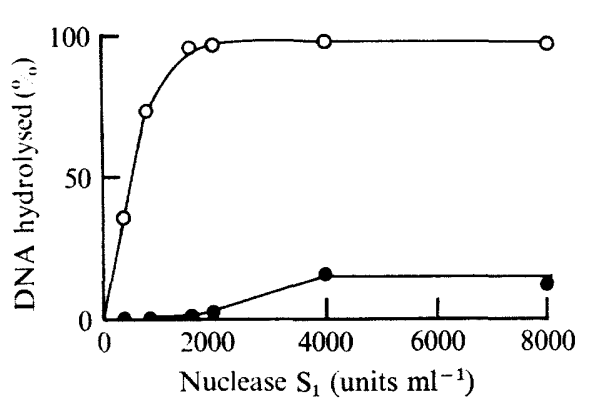

Fig. 2

Fig. I. Kinetics of DNA digestion by nuclease $S_{1}$. Thermally denatured or native DNA (0.5 $\mu \mathrm{g}$ of ${ }^{33}$ P-labelled $S$. flava IAM 2007 DNA supplemented with $100 \mu \mathrm{g}$ of unlabelled calf thymus DNA) was incubated with $\mathrm{I} 600$ units $\mathrm{ml}^{-1}$ of nuclease $\mathrm{S}_{1}$ at $35^{\circ} \mathrm{C}$ for various times. The DNA concentration of the reaction mixture was $20 \mu \mathrm{g} \mathrm{ml}^{-1}$. DNA hydrolysis was expressed as the percentage count recovered in the TCA-soluble fraction. - Native DNA; $\bigcirc$, denatured DNA.

Fig. 2. Effect of nuclease $S_{1}$ concentration on the digestion of thermally denatured and native DNA. Thermally denatured or native DNA was incubated with various concentrations of nuclease $S_{1}$ at $35^{\circ} \mathrm{C}$ for $15 \mathrm{~min}$. Other conditions were as for Fig. I. Native DNA; $O$, denatured DNA.

\section{RESULTS}

\section{DNA digestion by nuclease $S_{1}$}

Figure I shows the kinetics of DNA digestion by 1600 units of nuclease $S_{1} / m l$. Hydrolysis of thermally-denatured DNA reached a maximum at $96 \%$ after $20 \mathrm{~min}$, but native DNA was not hydrolysed during the same period of time. (Hydrolysis of native DNA never exceeded $5 \%$ in the standard experiments.) In the early stages of the reaction ( $15 \mathrm{~min}$ ), some digestion of native DNA was observed: this phenomenon was often encountered when the $\mathrm{NaCl}$ concentration was below $\mathrm{O}^{\mathrm{I}} \mathrm{M}$, but the reason for it is not known. The digestion of native DNA was also observed when nuclease $S_{1}$ was used in high concentrations (Fig. 2). At concentrations above 2000 units $/ \mathrm{ml}$, nuclease $S_{1}$ digested $15 \%$ of native DNA in 15 min. Nuclease $S_{1}$ action was found to depend upon ionic strength as reported by Sutton (I97I). In our case, the rate of DNA hydrolysis in the presence of $0.03 \mathrm{M}-\mathrm{NaCl}$ was $94 \%$ of that in the absence of $\mathrm{NaCl}$, and the inhibitory effect of $\mathrm{NaCl}$ on DNA hydrolysis increased with the $\mathrm{NaCl}$ concentration. The action of nuclease $\mathrm{S}_{1}$ on denatured and native DNA was independent of DNA concentration between 0.5 and $20 . \mathrm{I} \mu \mathrm{g} \mathrm{ml}^{-1}$.

\section{DNA hybridization}

The renaturation reaction of fully-denatured DNA is strongly influenced by the salt concentration and the temperature. Optimal renaturation is known to occur at about $25^{\circ} \mathrm{C}$ below the denaturation temperature, $T_{\mathrm{m}}$, and with a salt concentration above $0.4 \mathrm{M}$ (Marmur \& Doty, 196I; Wetmur \& Davidson, 1968). The Micrococcus and aerobic Sarcina DNAs that we studied had a high GC content (66 to $77 \%$ ) (Kocur, Bergan \& Mortensen, 1971) and their $T_{\mathrm{m}}$ values in SSC were around $98{ }^{\circ} \mathrm{C}$. For example, the $T_{\mathrm{m}}$ of $M$. lysodeikticus was $99.5^{\circ} \mathrm{C}$ (Marmur \& Doty, 1962). As the $T_{\mathrm{m}}$ was found to be very nearly a linear function of the logarithm of the ionic strength (Owen, Hill \& Lapage, 1969), the $T_{\mathrm{m}}$ of the M. lysodeikticus in $0.4 \mathrm{M}-\mathrm{NaCl}$ (the concentration used in this study) was expected to be above $100{ }^{\circ} \mathrm{C}$, and it was difficult to determine it accurately. Therefore, we chose the hybridization temperatures of 75 and $85{ }^{\circ} \mathrm{C}$ and compared the results. 
Table 2. DNA hybridization at 75 and $85^{\circ} \mathrm{C}$

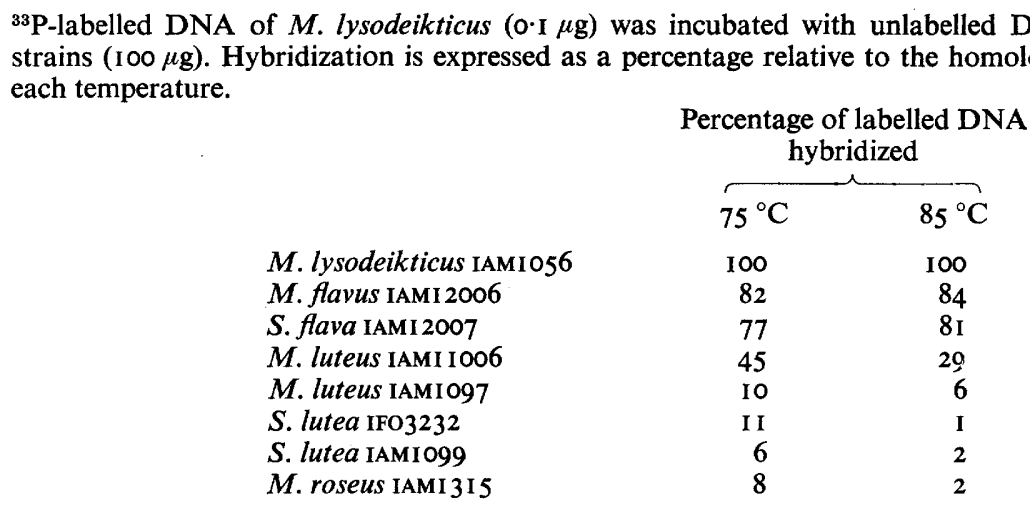

Table 2 compares the extent of hybridization of ${ }^{33} \mathrm{P}$-labelled $M$. lysodeikticus DNA with that of various other strains at 75 and $85{ }^{\circ} \mathrm{C}$. Hybridization was expressed as a percentage relative to the homologous system at each temperature. For strains showing high homology $(>80 \%$ ), the values were practically independent of temperature: for other strains (homo$\operatorname{logy}>50 \%$ ), the values at $85^{\circ} \mathrm{C}$ were lower than at $75^{\circ} \mathrm{C}$. The higher temperature tended to discriminate the DNA sequence homology more clearly but essentially the same DNA homology was observed at 75 and $85{ }^{\circ} \mathrm{C}$. We chose $75{ }^{\circ} \mathrm{C}$ as the hybridization temperature in the following experiments. The kinetics of DNA hybridization at $75{ }^{\circ} \mathrm{C}$ is shown in Fig. 3. In this experiment, we subtracted from the count the radioactivity due to selfannealing of ${ }^{33} \mathrm{P}$-labelled DNA which increased with time and reached $5 \%$ after $2 \mathrm{I} \mathrm{h}$. When ${ }^{33}$ P-labelled $M$. lysodeikticus DNA was hybridized with the homologous DNA, the percentage of hybridized DNA increased with time and reached a plateau at $83 \%$ after $9 \mathrm{~h}$. In subsequent experiments, the extent of hybridization of the homologous system varied from 74 to $96 \%$. On the other hand, when the labelled $M$. lysodeikticus DNA was hybridized with heterologous $M$. luteus IAMI097 DNA, the hybridization reached a plateau at $7 \%$ after $4 \mathrm{~h}$. In each DNA hybridization experiment, two or three samples were assayed after between $\mathrm{I} 2$ and $\mathrm{I} 8 \mathrm{~h}$ of incubation to ensure that the plateau had been reached.

\section{DNA homology and differential lysis by lytic enzymes}

Table 3 shows DNA homology values of test strains with the reference strains of $M$. lysodeikticus IAMI056, $S$. lutea IAMI099 and $M$. roseus IAMI3 5 by DNA hybridization at $75^{\circ} \mathrm{C}$, together with the mole percentage of guanine plus cytosine ( $\% \mathrm{GC}$ ) of DNAs (Kocur et al., I97I), the peptidoglycan types of cell walls (Schleifer \& Kandler, 1972) and the results of classification by cell-wall lytic enzymes. Repeats of most of the hybridization experiments gave essentially the same results. Nineteen strains fell into three groups on the basis of homology values. Group I contained nine strains with high homology (76 to $93 \%$ ) to $M$. lysodeikticus IAMI056, and $M$. luteus IAMI 1006 which had $48 \%$ homology to this reference strain. Group II consisted of four strains with high DNA homology ( $80 \%$ ) to $M$. roseus IAMI3I5. Group III consisted of five strains which showed homologies of between 27 and 9I \% to $S$. lutea IAMI099 but did not show significant homology to M. lysodeikticus IAMI056. Micrococcus luteus IAMI097, $M$. varians ATCCI9099 and ATCCI9I00, and $M$. conglomeratus IAMI459 and IAMI470 showed low homology to all three reference strains, and were not considered to belong to any of the three groups. Staphylococcus aureus IAMIOI I which is a 
Table 3. DNA homology of the various strains to the reference strains of $M$. lysodeikticus IAMI056, S. lutea IAMI099 and $M$. roseus IAMI3I 5 by DNA hybridization at $75^{\circ} \mathrm{C}$

\begin{tabular}{|c|c|c|c|c|c|c|c|c|c|}
\hline \multirow{2}{*}{$\begin{array}{c}\text { Group } \\
\text { I }\end{array}$} & \multirow[b]{2}{*}{ Strain } & \multicolumn{5}{|c|}{$\begin{array}{l}\text { Percentage DNA hybridized to } \\
\text { reference strains }\end{array}$} & \multirow{2}{*}{\multicolumn{2}{|c|}{$\begin{array}{c}\text { Peptido- } \\
\text { glycan } \\
\text { type } \dagger\end{array}$}} & \multirow[b]{2}{*}{$\begin{array}{l}\text { Lytic } \\
\text { enzyme }\end{array}$} \\
\hline & & \multicolumn{2}{|c|}{$\begin{array}{l}\text { M. lyso- } \\
\text { deikticus } \\
\text { IAMIOS6 }\end{array}$} & $\begin{array}{c}\text { M. roseus } \\
\text { IAMI3I5 } \\
3\end{array}$ & \multicolumn{2}{|c|}{$\begin{array}{r}\text { S. lutea } \\
\text { IAM1099 }\end{array}$} & & & \\
\hline I & $\begin{array}{l}\text { M. lysodeikticus IAMI056 } \\
\text { M. luteus IAMI I0IO } \\
\text { M. flavus IAM } 12005 \\
\text { M. flavus IAMI } 2006 \\
\text { S. flava IAMI } 2007 \\
\text { S. flava IAMI } 2008 \\
\text { S. subflava IAMI } 2009 \\
\text { S. lutea ATCC } 38 \text { I } \\
\text { S. lutea ATCC382 } \\
\text { M. luteus IAMI } 1006\end{array}$ & $\begin{array}{r}100 \\
79 \\
91 \\
84 \\
87 \\
85 \\
93\end{array}$ & $\begin{array}{l}76 \\
79\end{array}$ & 3 & $\begin{array}{r}8 \\
9 \\
10 \\
6 \\
7 \\
10 \\
8 \\
7\end{array}$ & 7 & $\begin{array}{l}70 \cdot 0,68 \cdot 6 \\
73 \cdot 4,70 \cdot 0 \\
73 \cdot 4,72 \cdot 8 \\
72 \cdot 0 \\
71 \cdot 0,72 \cdot 0\end{array}$ & $\left.\begin{array}{l}\mathrm{A} 2 \\
\mathrm{~A} 2 \\
\mathrm{~A} 2 \\
\mathrm{~A} 2 \\
\mathrm{~A} 2 \\
\mathrm{~A} 2\end{array}\right\}$ & Lysozyme \\
\hline II & $\begin{array}{l}M . \text { roseus IAMI } 315 \\
M . \text { roseus ATCC } 412 \\
M . \text { roseus ATCCI } 85 \\
M . \text { roseus IAMI } 295\end{array}$ & 10 & & $\begin{array}{r}100 \\
83 \\
83 \\
82\end{array}$ & $\begin{array}{l}14 \\
17 \\
13 \\
12\end{array}$ & $\begin{array}{r}6 \\
10\end{array}$ & $\begin{array}{l}69 \cdot 8,68 \cdot 0 \\
72 \cdot 8,69 \cdot 0 \\
71 \cdot 0,68 \cdot 0 \\
73 \cdot 3,70 \cdot 0\end{array}$ & $\left.\begin{array}{l}A 3 \alpha \\
A 3 \alpha \\
A 3 \alpha \\
A 3 \alpha\end{array}\right\}$ & $\begin{array}{l}\text { Kyowa's } \\
\text { 'lytic } \\
\text { enzyme 2' }\end{array}$ \\
\hline III & $\begin{array}{l}\text { S. lutea IAMI } 099 \\
\text { S. lutea IFO3232 } \\
\text { S. lutea ATCC } 383 \\
\text { M. varians ATCC } 399 \\
\text { St. lactis ATCCI } 5306\end{array}$ & $\begin{array}{l}8 \\
9\end{array}$ & $\begin{array}{l}9 \\
7 \\
6\end{array}$ & 6 & $\begin{array}{r}100 \\
99 \\
40\end{array}$ & $\begin{array}{r}100 \\
91 \\
36 \\
35 \\
27\end{array}$ & $69 \cdot 3,69 \cdot 0$ & $\left.\begin{array}{l}\text { A3 } \alpha \\
\text { A3 } \alpha \\
\text { A3 } \\
\text { A3 } \alpha\end{array}\right\}$ & $\begin{array}{l}\text { Streptomyces } \\
\text { albus G } \\
\text { enzyme }\end{array}$ \\
\hline & $\begin{array}{l}\text { M. luteus IAMI } 097 \\
M . \text { varians ATCCI } 9099 \\
M . \text { varians ATCCI } 9100 \\
M . \text { conglomeratus IAMI } 459 \\
\text { M. conglomeratus IAMI } 470\end{array}$ & $\begin{array}{l}6 \\
8\end{array}$ & $\begin{array}{r}13 \\
9\end{array}$ & $\begin{array}{l}2 \\
5 \\
1 \\
2\end{array}$ & $\begin{array}{l}8 \\
7\end{array}$ & $\begin{array}{l}7 \\
6 \\
3 \\
2\end{array}$ & $\begin{array}{l}71 \cdot 4,68 \cdot 0 \\
72 \cdot 0,69 \cdot 0\end{array}$ & $\left.\begin{array}{l}\mathrm{A}_{4} \alpha \\
\mathrm{A}_{3} \alpha \\
\mathrm{A}_{3} \alpha \\
\mathrm{A}_{4} \gamma \\
\mathrm{A}_{4} \gamma\end{array}\right\}$ & Lysozyme \\
\hline & St. aureus IAMIOI I & 4 & & & 5 & & $37 \cdot 7,35 \cdot 7$ & Ao & $\begin{array}{l}\text { 'Lytic } \\
\text { enzyme 2' }\end{array}$ \\
\hline
\end{tabular}

* Results from Kocur et al. (1971).

$\dagger$ Results from Schleifer \& Kandler (1972). Peptidoglycan types were: A2, L-Lys-D-Ala-L-Lys-D-Glu (Gly)-L-Ala; A3 $\alpha$, L-Lys-L-Ala ${ }_{3-4} ;$ A4 $\alpha$, L-Lys-Gly-L-Glu; A4 $\gamma, m$-Dpm-D-Glu ${ }_{2} ;$ Ao, L-Lys-Gly ${ }_{5}$ (mesoDiaminopimelic acid: $m$-Dpm).

typical member of Staphylococcaceae did not show significant homology to M. lysodeikticus IAM 1056 or S. lutea IAMI099.

The reproducibility of the homology values obtained by this method was tested by duplicate runs of experiments using $S$. lutea IAM 099 as reference strain (Table 3). Another check was carried out by changing the reference strain reciprocally, i.e. S. flava IAMI 2007 DNA was labelled and renatured with unlabelled $M$. lysodeikticus and S. lutea IFO3232 DNAs. The homology values obtained were 87 and $12 \%$ respectively, showing good agreement with the 87 and $9 \%$ obtained when $M$. lysodeikticus was used as the reference strain (Table 3).

\section{Thermal dissociation of hybridized DNA}

Laird, McConaughy \& McCarthy (1969) showed that the $T_{\mathrm{m}}$ of heteroduplex DNA decreased with the increase in mispaired bases. To examine the extent of mispairing in hybridized DNA, we studied the thermal dissociation profiles of hybridized DNA. Figure 4 shows thermal dissociation profiles in $0 . \mathrm{I} \mathrm{M}-\mathrm{NaCl}$ of a homoduplex of $M$. lysodeikticus 


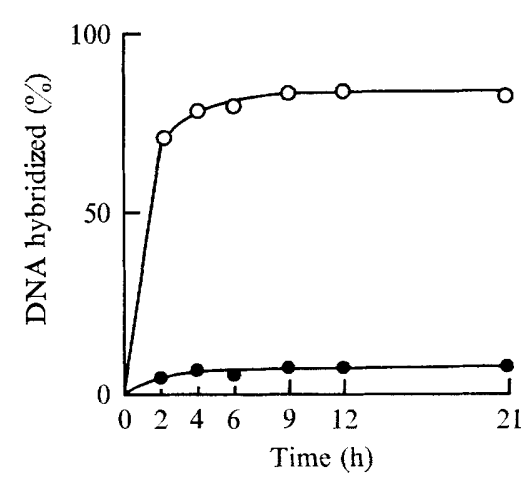

Fig. 3

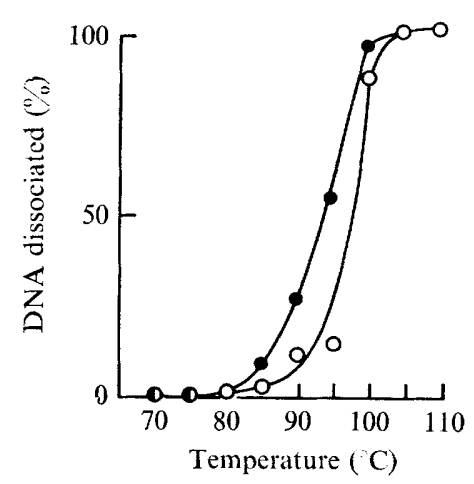

Fig. 4

Fig. 3. Kinetics of the hybridization of homologous and heterologous DNA at $75{ }^{\circ} \mathrm{C} .{ }^{33} \mathrm{P}-$ labelled DNA of $M$. lysodeikticus IAMI056 (0.1 $\mu \mathrm{g}$ ) was incubated with $100 \mu \mathrm{g}$ of $M$. lysodeikticus IAMI056 (homologous) or $M$. luteus IAMI097 (heterologous) at $75^{\circ} \mathrm{C}$ for various times. After hybridization, the unhybridized DNA was digested by nuclease $S_{1}$. Hybridized DNA is expressed as the percentage radioactivity recovered in the TCA-insoluble fraction. $O$, Heterologous DNA; $O$, homologous DNA.

Fig. 4. Thermal dissociation profile of hybridized DNA. After ${ }^{33}$ P-labelled DNA of $M$. lysodeikticus IAMI056 (0.1 $\mu \mathrm{g})$ was incubated with $100 \mu \mathrm{g}$ of unlabelled $M$. lysodeikticus IAMI056 DNA (homologous) or $S$. flava IAMI 2007 DNA (heterologous) at $75^{\circ} \mathrm{C}$ for $15 \mathrm{~h}$, the hybrid DNA solution was diluted with three volumes of distilled water $(0 \cdot 1 \mathrm{M}$ with respect to $\mathrm{NaCl})$, heated at various temperatures for $15 \mathrm{~min}$ and cooled rapidly followed by the addition of nuclease $\mathrm{S}_{1}$. Dissociated DNA is expressed as the percentage radioactivity recovered in the TCA-soluble fraction. $O$, Heterologous DNA; O, homologous DNA.

IAMI056 DNA and a heteroduplex of $M$. lysodeikticus IAMI056 DNA with $S$. flava IAMI 2007 DNA after DNA hybridization at $75{ }^{\circ} \mathrm{C}$. The $T_{\mathrm{m}}$ of $M$. lysodeikticus IAMIo56 homoduplex was $97^{\circ} \mathrm{C}$. This agreed with the $T_{\mathrm{m}}$ value of $95^{\circ} \mathrm{C}$ reported for DNA from the same strain of $M$. lysodeikticus under similar conditions (Owen et al., 1969), which suggested that pairing was complete in the hybridized homoduplex. On the other hand, the $T_{\mathrm{m}}$ of the heteroduplex with S. flava IAMI 2007 was $93.5{ }^{\circ} \mathrm{C}$, which was $3.5{ }^{\circ} \mathrm{C}$ lower than that of the homoduplex. Anderson \& Ordal (1972) reported that $\Delta T_{\mathrm{m}}$, the decrease in $T_{\mathrm{m}}$ of a heteroduplex, increased linearly with the decrease in percentage of DNA homology. Sarcina flava IAM I 2007 showed $87 \%$ homology to $M$. lysodeikticus IAMI 056. Our results agreed with the relationship given by Anderson \& Ordal (I972), i.e. $4.25 \%$ decrease in homology per degree C of $\Delta T_{\mathrm{m}}$.

\section{DISCUSSION}

We have classified 25 strains of Micrococcus, Sarcina and Staphyloccus: I9 fell into three groups (groups I, II, III) but six strains did not belong to any of these groups (Table 3 ). Our classification agrees with the grouping by types of peptidoglycan in bacterial cell walls (Schleifer \& Kandler, 1972). All bacterial strains of group I have A2 type peptidoglycan and were lysed with lysozyme. Group II and group III strains have the A3 $\alpha$ type peptidoglycan. Group II strains were lysed with 'lytic enzyme 2' but not with lysozyme, while group III strains were lysed with Streptomyces albus G lytic enzyme but not with lysozyme or 'lytic enzyme 2'. The differential action of 'lytic enzyme 2' on group II and group III strains suggests the existence of some difference in cell-wall constitution between the two groups. From these results, it seems that bacterial strains of genetically related groups have similar cell-wall structures. It should be noted, however, that five strains which did not belong to 
any of the three groups were lysed with lysozyme, and $M$. varians ATCCI9099 and ATCCI9100 having $\mathrm{A}_{3} \alpha$ type peptidoglycan did not belong to group II or group III.

Genetic homology among various bacterial strains can be estimated by genetic transformation, which is known to parallel the results obtained with DNA hybridization. Kloos (1969) found that $M$. lysodeikticus ATCC4698 (IAMI056), M. flavus ATCC400 (IAMI 2005), $S$. flava AтCC540 (IAmi 2008), S. lutea ATCC272 (M. luteus iAmiloIo), S. lutea AтCC38I, $S$. lutea ATCC382 and $S$. subflava ATCC7468 (IAMI2009) among many others were able to transform adeninz, histidine and tryptophan auxotrophs of $M$. lysodeikticus strain ISU to prototrophy at relatively high frequency, while $M$. roseus ATCC4I 2 and ATCC98I 5 (IAMI 295), $M$. rubens ATCCI 86 ( $M$. roseus IAMI 3 I5), $M$. varians ATCC399, $M$. luteus ATCC398 (IAMI097) and others failed to transform them. Taking Kloos' and our results together, it is clear that all strains belonging to our group I had high transforming ability toward M. lysodeikticus, while the strains not belonging to group I invariably failed to transform. Thus the results of transformation support our grouping by DNA homology.

In Bergey's Manual of Determinative Bacteriology (1974) the genus Micrococcus is divided into three species- $M$. luteus, $M$. roseus and $M$. varians-by physiological and biochemical characteristics and the GC content of DNA. This classification essentially agrees with our grouping on the basis of DNA homology, i.e. our group I corresponds to $M$. luteus, group II to $M$. roseus and group III to $M$. varians. The reference strains of group I and II are the neotype strains of $M$. luteus and $M$. roseus. As Table 3 shows, the homology among group II strains is very high ( $>80 \%$ ), while group III consists of two types of strains, one showing over $90 \%$ DNA homology and the other showing between 27 and $36 \%$ homology to $S$. lutea IAM 1099. Furthermore, $M$. luteus IAM I 1006 in our group I shows an exceptionally low DNA homology value compared with other strains of group I. Further investigation might justify division of groups I and III.

Five strains of Micrococcus could not be assigned to any of the three groups on account of their low DNA homology to the reference strains used. Micrococcus luteus IAMI097 was not considered to belong to group I because of its low GC content (66\%); different peptidoglycan type (A $4 \alpha$ ) and menaquinone pattern (Jeffries et al., I965); and other characteristics (Kloos, 1969), which is in agreement with our results. Micrococcus varians ATCCI9099 and ATCCI9I0O, and $M$. conglomeratus IAMI 459 and IAMI470 were isolated from petroleum brines in Japan by lizuka \& Komagata (1965), and the latter two strains have a peptidoglycan type (A4 $\gamma$ ) which is not found among the strains of the three groups. Possibly these five strains belong either to some groups other than the three groups of Micrococcus or to some genus or genera other than Micrococcus. Any conclusion, however, must await further investigation.

This study also confirms the usefulness of the hybridization method using nuclease $S_{1}$ in estimating DNA homology among various bacterial strains, as claimed earlier by Crosa et al. (1973). The method is convenient for treating many samples and gives fairly reproducible results even if the labelled reference DNA and unlabelled DNA are exchanged. This is probably due to the endonucleolytic nature of nuclease $S_{1}$, which removes the unpaired portion of DNA very precisely, even distinguishing nicks on T5 bacteriophage DNA (Shishido \& Ando, 1975)

Another feature of this study is the evaluation of cell-wall lytic enzymes as an accurate, reproducible and rapid method for classification. The three groups determined by the DNA hybridization procedure coincide fairly well with the results of a simple cell lysis test by three types of cell-wall lytic enzymes. The test by lytic enzymes sometimes gives closer classification than that by the peptidoglycan types studied by Schleifer \& Kandler (1972). 
More detailed taxonomic studies will be made possible by introducing other lytic enzymes.

The authors are grateful to Professor S. Kotani of the University of Osaka for kindly supplying Streptomyces albus G enzyme, and to Professor K. Komagata of the University of Tokyo for supplying strains and for valuable discussion.

\section{REFERENCES}

AAIJ, C. \& Borst, P. (1972). The gel electrophoresis of DNA. Biochimica et biophysica acta 269, 192-200. Allet, B., JepPesen, P. G. N., Katagiri, K. J. \& Delius, H. (1973). Mapping the DNA fragments produced by cleavage of $\lambda$ DNA with endonuclease RI. Nature, London 24I, I $20-122$.

ANDERSON, R. S. \& ORDAL, E. J. (1972). Deoxyribonucleic acid relationships among marine vibrios. Journal of Bacteriology ro9, 696-706.

ANDo, T. (1966). A nuclease specific for heat-denatured DNA isolated from a product of Aspergillus oryzae. Biochimica et biophysica acta 114, I 58-168.

Bergey's Manual of Determinative Bacteriology, 8th edn. (1974). Edited by R. E. Buchanan and N. E. Gibbons. Baltimore: Williams \& Wilkins.

Boling, M. E. (1972). Homology between the deoxyribonucleic acids of Haemophilus influenzae and Haemophilus parainfluenzae. Journal of Bacteriology 112, 745-750.

Brenner, D. J., Fanning, G. R., Johnson, K. E., Citarella, R. V. \& Falkow, S. (1969). Polynucleotide sequence relationships among members of Enterobacteriaceae. Journal of Bacteriology 98, 637-650.

Brenner, D. J., Fanning, G. R., Skerman, F. J. \& Falkow, S. (1972). Polynucleotide sequence divergence among strains of Escherichia coli and closely related organisms. Journal of Bacteriology rog, 953-965.

Crosa, J. H., Brenner, D. J. \& Falkow, S. (1973). Use of a single-strand specific nuclease for analysis of bacterial and plasmid deoxyribonucleic acid homo- and heteroduplexes. Journal of Bacteriology 115 , 904-9II.

De Ley, J., Tiutgat, R., De Smedt, J. \& Michiels, M. (1973). Thermal stability of DNA: DNA hybrids within the genus Agrobacterium. Journal of General Microbiology 87, 24I-252.

HưbaleK, Z. (1969). Numerical taxonomy of genera Micrococcus Cohn and Sarcina Goodsir. Journal of General Microbiology 57, 349-363.

Irzuka, H. \& Komagata, K. (1965). Microbiological studies on petroleum and natural gas. III. Determination of Brevibacterium, Arthrobacter, Micrococcus, Sarcina, Alcaligenes and Achromobacter. Journal of General and Applied Microbiology II, I-14.

Jeffries, L., Cawthorne, M. A., Harris, M., Cook, B. \& Diplock, A. T. (I965). Menaquinone determination in the taxonomy of Micrococcaceae. Journal of General Microbiology 54, 365-380.

KLoos, W. E. (1969). Transformation of Micrococcus lysodeikticus by various members of the family Micrococcaceae. Journal of General Microbiology 59, 247-255.

KocUR, M. \& MARTINEC, T. (I965). Some remarks on the classification of micrococci. International Bulletin of Bacteriological Nomenclature and Taxonomy I5, I I3-I 14.

Kocur, M., Bergan, T. \& MorTensen, N. (I97I). DNA base composition of Gram-positive cocci. Journal of General Microbiology 69, $167-183$.

Laird, C. D., McConaughy, B. L. \& MCCARThy, B. J. (1969). Rate of fixation of nucleotide substitutions in evolution. Nature, London 224, 149-1 54.

Marmur, J. \& Doty, P. (196I). Thermal renaturation of deoxyribonucleic acids. Journal of Molecular Biology 3, 585-594.

Marmur, J. \& DotY, P. (I962). Determination of the base composition of deoxyribonucleic acid from its thermal denaturation temperature. Journal of Molecular Biology 5, I09-I I 8.

MCCARTHY, B. J. \& BolTon, E. T. (1963). An approach to the measurement of genetic relatedness among organisms. Proceedings of the National Academy of Sciences of the United States of America 50, I 56-164.

OKANISHI, M. \& GREGORY, K. I. (1970). Methods for the determination of deoxyribonucleic acid homologies in Streptomyces. Journal of Bacteriology ro4, 1086-1094.

Okanishi, M., Akazawa, H. \& Umezawa, H. (1972). An evaluation of taxonomic criteria in Streptomycetes on the basis of deoxyribonucleic acid homology. Journal of General Microbiology 72, 49-58.

Owen, R. J., Hill, L. R. \& LAPAGE, S. P. (1969). Determination of DNA base compositions from melting profiles in dilute buffers. Biopolymers $7,503-516$.

Petit, J. F., Munoz, E. \& GhuYsen, J. M. (I966). Peptide cross-links in bacterial cell wall peptidoglycans studied with specific endopeptidases from Streptomyces albus G. Biochemistry, New York 5, 2764-2776.

Saito, H. \& Miura, K. (1963). Preparation of transforming deoxyribonucleic acid by phenol treatment. Biochimica et biophysica acta 72, 619-629. 
Schildkraut, C. L., Marmur, J. \& Doty, P. (1961). The formation of hybrid DNA molecules and their use in studies of DNA homologies. Journal of Molecular Biology 3, 595-617.

SChleIFER, K. H. \& KANDleR, O. (1972). Peptidoglycan types of bacterial cell walls and their taxonomic implications. Bacteriological Reviews 36, 407-477.

ShIsHIDo, K. \& ANDO, T. (1975). Site-specific fragmentation of bacteriophage T5 DNA by single-strandspecific endonuclease. Biochimica et biophysica acta 390, I25-132.

Sutron, W. D. (1971). A crude nuclease preparation suitable for use in DNA reassociation experiments. Biochimica et biophysica acta 240, 522-53I.

WeTMUR, J. G. \& DAVIDSON, N. (1968). Kinetics of renaturation of DNA. Journal of Molecular Biology 3r, 349-370. 